\title{
Circulating Adipocyte Fatty Acid Binding Protein (A-FABP): Predictor of Metabolic Syndrome in Patients with Type 2DM
}

\author{
EMAN S. EL-HADIDI, M.D.*; WESSAM EL-SAYED, M.D.*; DOAA M.A. ELZOGHBY, M.D.*; \\ MARAM M.M. MAHDY, M.D.** and SAFEYA M. ADEL, M.Sc.*** \\ The Departments of Clinical Pathology*, InternalMedicine**, Faculty of Medicine, Ain Shams University and \\ Clinical Pathology***, Ministry of Health
}

\begin{abstract}
Background: The circulating portion of adipocyte fatty acid binding protein (A-FABP) acts as a humoral factor potentially controlling inflammatory responses and insulin action in adipocyte. Most individuals with Type 2 diabetes mellitus (2DM) exhibit intra-abdominal obesity, insulin resistance and subsequent occurrence of metabolic syndrome (MetS)

Aim of Study: This work aimed at evaluating A-FABP as a marker for MetS in type 2DM.

Subjects and Methods: The study included (180) subjects divided into group I (120) adult patients with type 2DM diagnosed according to ADA 2016. They were subdivided into subgroup Ia (60 without MetS) and subgroup Ib (60 with MetS). Group II (control group) included (60) age- and sexmatched apparently healthy subjects. Circulating A-FABP was measured by ELISA. In addition, assay of fasting insulin (F.insulin), lipid profile, hsCRP, and calculation of HOMAIR.
\end{abstract}

Results: Highly significant increase in levels of A-FABP, F.insulin, HOMA-IR and hsCRP was observed in subgroup Ia compared to control group (Z: 5.691,4.902, 5.908, and $0.477 ; p<0.01$; respectively). Sub-group Ib versus sub-group Ia revealed significant elevated levels of A-FABP and F.Insulin (Z: 5.276, $p<0.01$ and Z: 2.469, $p<0.05$; respectively) while HOMA-IR and hsCRP showed no significant difference between both subgroups $(p>0.05)$. In subgroup $\mathrm{Ib}$, there was a significant positive statistical correlation between A-FABP and weight and BMI ( $r: 0.379$ and $0.386, p<0.05$; respectively). Stepwise multi-regression analysis indicated that triglycerides and A-FABP are the most sensitive independent predictors of MetS in diabetic patients (F-ratio:64.4 and $p<0.001$ ).

Conclusion: High serum A-FABP level is strongly associated with MetS in type 2DM. It is a promising independent marker of MetS and is beneficial in its early diagnosis.

Key Words: Type 2DM-Metabolic syndrome - A-FABPELISA - predictor.

Correspondence to: Dr. Doaa M.A. Elzoghby, E-Mail: doaa elzoghby@yahoo.com

\section{Introduction}

THE association between excessive body weight and many diseases, particularly type 2 diabetes mellitus has been proved in various studies [1] Besides lipid accumulation and free fatty acids (FFA) release, adipocytes together with adipose tissue stromal cells produce and release multiple signaling proteins termed adipokines. Adipocyte fatty acid binding protein (A-FABP) is a new adipokine suggested to be linked to obesity, insulin resistance, impaired glucose metabolism and eventually development of metabolic syndrome (MetS) $[2,3]$

Although A-FABP was originally identified as an abundant cytoplasmic protein in adipocytes, a portion of A-FABP is released into bloodstream. Circulating A-FABP is elevated in obese individuals and correlates positively with the features of the metabolic syndrome, and the incidence of atherosclerosis and cardiovascular diseases [4]. Accordingly, this study investigated the possible association between serum levels of A-FABP and the presence of MetS in type 2 diabetes mellitus, as well as its evaluation as a predictor marker for MetS in these patients.

\section{Subjects and Methods}

\section{A- Subjects:}

This study was conducted on (120) adult diabetic patients (group I) diagnosed according to the American Association of Diabetes, 2016 criteria for diagnosis of DM [5] presented to Endocrinology Department, Ain Shams University Hospital, Cairo, Egypt, between November 2017 and January 2019, and their matching (60) apparently healthy subjects serving as control group. Group I patients were 
further subdivided into 2 subgroups; subgroup Ia which included 60 diabetic patients without MetS (22 males and 38 females) and subgroup Ib included 60 diabetic patients with metabolic syndrome (26 males and 34 females). Patients enrolled in subgroup $\mathrm{Ib}$ were selected according to the inclusion criteria for MetS by National Cholesterol Education Program Adult Treatment Panel III (NCEP ATP III) [6] .

Exclusion criteria: Patients were excluded if they have

- Acute infection.

- Acute myocardial infarction.

- Heart failure.

- Malignancy at the time of sampling.

An informed consent was taken from all subjects participating in the study before history taking, physical examination and blood sample withdrawal. The procedures applied in this study were approved by The Ethical Committee of Human Experimentation of Ain Shams University, and are in accordance with the Helsiniki Declaration of 1975.

All subjects included in the study had detailed medical history taking, blood pressure measurement, anthropometric measures (weight, height, BMI calculation and waist circumference), measurement of fasting and 2 hours postprandial serum glucose, glycated haemoglobin (HbA1c), total cholesterol, triglycerides (TG), high-density lipoprotein cholesterol (HDL-C), low-density lipoprotein cholesterol (LDL-C), fasting serum insulin level, highly sensitive C-reactive protein (hsCRP), insulin resistance evaluated using a homeostasis model assessment of insulin resistance (HOMAIR) and serum A-FABP level.

\section{B- Sampling:}

Under complete aseptic conditions, $10 \mathrm{~mL}$ of fasting venous blood were obtained by a clean venipuncture, two milliliters were placed in EDTA tube for subsequent assay of $\mathrm{HbA} 1 \mathrm{c}$, while the rest was evacuated in two plain test tubes. The serum was separated by centrifugation (1000x g for 15 minutes). Serum of one tube was immediately assayed for fasting serum glucose and lipid profile (cholesterol, triglycerides, HDL-C and LDL-C), while the serum collected in the other tube was divided in two aliquots and stored at $-20^{\circ} \mathrm{C}$ for subsequent assay of hsCRP, fasting insulin and AFABP. Two hours postprandial sample for glucose was collected, separated by centrifugation and assayed. Hemolysed samples were discarded. Repeated freezing and thawing was avoided.

\section{C- Methods:}

\section{Analytical methods:}

$\mathrm{HbA1c}$ was assayed by high performance liquid chromatography (HPLC) technique on the BioRad d- 10 hemoglobin testing system (Bio-Rad Laboratories, Inc., 4000 Alfred Nobel Drive, Hercules, California 94547, USA) using reagents supplied by the company. Serum samples were assayed for glucose and lipid profile on the Beckman AU-680 system auto-analyzer (Beckman Coulter, Inc. Diagnostics Division Headquarters 250 South Kraemer Boulevard Brea, California 928216232 USA) using reagents supplied by the company.

Fasting serum insulin was assayed by commercially available ELISA kit supplied by Chemux BioScience, Inc (50 South Linden Ave., 7, South San Francisco, CA 94080, USA). Serum A-FABP was assayed by commercially available sandwich ELISA kit supplied by Elabscience Biotechnology Inc., USA (Building B 18, 2 nd Phase of Biomedical Park, 858 Gaoxin Road, Donghu Hi-Tec Development Area, Wuhan, Hubei, USA). hsCRP was measured by immunoturbidimetry using reagents supplied from Biosystem S.A (Bio System S.A, Costa Brava, 30.08030 Barcelona Spain) on automated BioMaxima instrument (BioMaxima S.A. 20-277 Lublin, Vetterow 5, Poland).

\section{Calculation of results:}

Fasting glucose $(\mathrm{m} / \mathrm{dL}) \mathrm{x}$

HOMA-IR = Fasting insulin $(\mathrm{IU} / \mathrm{mL})$

$$
405
$$

Cutoff point to define insulin resistance corresponds to HOMA-IR >_3.8 [7].

\section{A-FABP and Fasting insulin:}

Construction of a standard curve is done by plotting the mean absorbance for each standard on the $y$-axis against the concentration on the $\mathrm{x}$-axis and drawing a best fit curve through the points on the graph. If samples have been diluted, the concentration read from the standard curve must be multiplied by the dilution factor.

hsCRP:

Agglutination between hsCRP in a sample and anti hsCRP is detected as an absorbance change $(570 \mathrm{~nm})$, with the magnitude of the change being proportional to the quantity of hsCRP in the sample. The actual concentration is then determined by the interpolation from a calibration curve prepared from calibrators of known concentration [8]. 


\section{Statistical methods:}

All statistical analyses were done using software version IBM SPSS (Statistical Package for the Social Sciences) statistics (Version 25.0, IBM Corp., USA, 2017-2018). Data were expressed descriptively as median and interquartile range (IQR) for quantitative non parametric values and as percent for qualitative data. Comparative statistics were done using the Wilcoxn Rank Sum test and Kruskall Wallis test for non parametric data. Correlation analysis was performed using Spearman's rank correlation coefficient $(r)$ for non parametric data. Receiver operator characteristic (ROC) curves were constructed and optimal cutoff values for serum A-FABP and triglycerides were established by the best sensitivity and specificity where the right angle at the upper left corner is the best diagnostic threshold (cut-off) of the parameter being varied. Logestic multi-regression analysis was used to search for a panel (independent parameters) that can predict the target parameter (dependant variable).In all statistical analyses, pvalue $>0.05$ : Non significant; $p$-value $<0.05$ : Significant; $p$-value <0.01: Highly significant.

\section{Results}

Descriptive and comparative statistics of different studied parameters among group Ia, Ib (patient subgroup) and group II (control group) using Kruskall-Wallis Test are seen in Table (1).

Table (2) shows statistical comparison between subgroup Ia versus group II Using Wilcoxn Rank Sum Test.
Table (3) shows comparative statistical analysis using Wilcoxn Rank Sum Test, between subgroup $\mathrm{Ib}$ versus subgroup Ia.

Using Ranked Sperman Correlation Test, correlation analysis of A-FABP and other studied parameters in subgroup $\mathrm{Ib}$, revealed a significant positive statistical correlation between A-FABP and weight as well as BMI ( $r: 0.379$ and 0.386, $p<0.05$; respectively), in the studied population. However no significant statistical correlation is seen between A-FABP and other studied parameters $(p>0.05)$.

Stepwise multi-regression analysis in Table (4) examined the effect of different parameters on AFABP. Each non significant parameters is removed in a stepwise manner to reach the final step with TG, which indicated that TG and A-FABP are the most sensitive independent predictors of MetS in diabetic patients, and eliminates the role of HOMAIR, F.Insulin and hsCRP as predictors of the disease, with (F. Ratio=64.4 and $p=0.001)$ and the coefficient variant zero reflects that prediction formula for MetS in type $2 \mathrm{DM}=-0.175+0.005(\mathrm{TG})+$ 0.095 (A-FABP).

Table (5) shows Receiver Operating Characteristic Curve (ROC) curve analysis for diagnostic performance of TG, A-FABP and their combination for discriminating sub-group Ib from combined sub-group Ia and group II (AUC; TG: 0.678, A.FABP: 0.904,combined TG and A-FABP:0.987).

Table (1): Descriptive and comparative statistics of different studied parameters among SubGroups Ia,Ib and Group II.

\begin{tabular}{|c|c|c|c|c|c|}
\hline Parameter & $\begin{array}{l}\text { Subgroup Ia }(\mathrm{n}=60) \\
\text { Median }(\mathrm{Q} 1-\mathrm{Q} 3)\end{array}$ & $\begin{array}{l}\text { Subgroup } \mathrm{Ib}(\mathrm{n}=60) \\
\text { Median }(\mathrm{Q} 1-\mathrm{Q} 3)\end{array}$ & $\begin{array}{l}\text { Control group (II) }(\mathrm{n}=60) \\
\text { Median }(\mathrm{Q} 1-\mathrm{Q} 3)\end{array}$ & $\mathrm{H}$ & $p$ \\
\hline Weight (Kg) & $83(68.75-90.25)$ & $100(84.5-110)$ & $72.5(68-85.25)$ & 23.543 & $<0.01$ \\
\hline Height $(\mathrm{cm})$ & $166.5(160-170.25)$ & $165(160-172.5)$ & $170(162.25-175)$ & 2.763 & $>0.05$ \\
\hline BMI $\left(\mathrm{Kg} / \mathrm{m}^{2}\right)$ & $28.25(26.5-32)$ & $35.5(29-40)$ & $26(24-28.25)$ & 35.238 & $<0.01$ \\
\hline Waist $(\mathrm{cm})$ & $86(78-95.75)$ & $109(94.5-120.5)$ & $83.5(78.75-91.25)$ & 27.429 & $<0.01$ \\
\hline FBS $(\mathrm{mg} / \mathrm{dL})$ & $138.5(101.75-173.75)$ & $125.5(101.5-158.25)$ & $80(75.75-86)$ & 52.657 & $<0.01$ \\
\hline $2 \mathrm{hPP}(\mathrm{mg} / \mathrm{dL})$ & $191.5(147.25-262.75)$ & $203.5(170.75-275)$ & $97(89.75-104)$ & 51.223 & $<0.01$ \\
\hline $\mathrm{HbA1c}(\%)$ & $6.9(6.15-9.25)$ & $7.35(6.357-8.6)$ & $5.2(5-5.3)$ & 56.846 & $<0.01$ \\
\hline T.Chol (mg/dL) & $170.5(144.25-206.25)$ & $191(164-239.25)$ & $165(139-191)$ & 5.937 & $>0.05$ \\
\hline $\mathrm{TG}(\mathrm{mg} / \mathrm{dL})$ & $122.5(87.5-148)$ & $148(111.5-196.5)$ & $93(84.5-122.25)$ & 19.683 & $<0.01$ \\
\hline HDL-C (mg/dL) & $50.5(43.25-57.25)$ & $44.5(39.75-49.75)$ & $54(46.5-60.25)$ & 9.035 & $<0.05$ \\
\hline LDL-C (mg/dL) & $100.5(77.5-117.75)$ & $111.5(86.25-150.75)$ & $111(97-123.75)$ & 3.052 & $>0.05$ \\
\hline F.Insulin ( IU⿴囗十) & $11.5(5-20.5)$ & $19(10.75-25)$ & $8.5(5.375-12)$ & 22.785 & $<0.01$ \\
\hline HOMA-IR & $3.95(2.175-7.9)$ & $5.6(3-9.375)$ & $1.65(0.975-2.225)$ & 39.109 & $<0.01$ \\
\hline A-FABP (ng/mL) & $3.4(0.2-6)$ & $10.5(8.25-14.25)$ & $1.5(0.675-2.625)$ & 41.389 & $<0.01$ \\
\hline hsCRP (mg/dL) & $0.4485(0.153-0.578)$ & $0.6185(0.282-1.218)$ & $0.155(0.079-0.235)$ & 2.6106 & $<0.01$ \\
\hline
\end{tabular}

$p$-value $>0.05$ : Non significant. $\quad p$-value $<0.05$ : Significant. $\quad p$-value $<0.01$ : Highly significant. 
Table (2): Comparative statistics between SubGroup Ia versus Group II and Subgroup Ib versus Group (II) as regard different studied parameters.

\begin{tabular}{lcccc}
\hline \multirow{2}{*}{ Group } & \multicolumn{2}{c}{$\begin{array}{c}\text { Subgroup Ia vs } \\
\text { Control group (II) }\end{array}$} & \multicolumn{2}{c}{$\begin{array}{c}\text { Subgroup Ib vs } \\
\text { Control group (II) }\end{array}$} \\
\cline { 2 - 5 } & $\mathrm{Z}$ & $p$ & $\mathrm{Z}$ & $p$ \\
\hline F.Insulin ( iIU/mL) & 1.986 & $<0.05$ & 4.902 & $<0.001$ \\
HOMA-IR & 4.533 & $<0.01$ & 5.908 & $<0.001$ \\
A-FABP (ng/mL) & 1.371 & $>0.05$ & 5.691 & $<0.001$ \\
hSCRP (mg/dL) & 0.366 & $<0.01$ & 0.477 & $<0.001$ \\
\hline
\end{tabular}

$p$-value $>0.05$ : Non significant.

$p$-value $<0.05$ : Significant.

$p$-value $<0.01$ : Highly significant.

Table (3): Comparative statistics between SubGroup Ib versus SubGroup Ia as regard different studied parameters.

\begin{tabular}{lcc}
\hline Parameter & $\mathrm{Z}$ & $p$ \\
\hline F.Insulin $(\mu \mathrm{IU} / \mathrm{mL})$ & 2.469 & $<0.05$ \\
HOMA-IR & 1.715 & $>0.05$ \\
A-FABP $(\mathrm{ng} / \mathrm{mL})$ & 5.276 & $<0.01$ \\
hsCRP $(\mathrm{mg} / \mathrm{dL})$ & 0.172 & $>0.05$ \\
\hline
\end{tabular}

$p$-value $>0.05$ : Non significant.

$p$-value $<0.05$ : Significant.

$p$-value $<0.01$ : Highly significant.

Table (4): Stepwise logistic multi-regression analysis for different studied parameters using groups as dependent variable.

\begin{tabular}{lllllll}
\hline Item & $\begin{array}{l}\text { Reg. } \\
\text { Coef. }\end{array}$ & \multicolumn{1}{c}{$t$} & $p$ & Sig. & $\begin{array}{c}\text { F- } \\
\text { ratio }\end{array}$ & $p$ \\
\hline (Constant) & -0.175 & -1.237 & 0.219 & $>0.05$ & & \\
TG (mg/dL) & 0.005 & 5.233 & 0 & $<0.01$ & & \\
$\begin{array}{c}\text { A.FABP } \\
(\mathrm{ng} / \mathrm{mL})\end{array}$ & 0.095 & 8.93 & 0 & $<0.01$ & & \\
& & & & & 64.368 & $<0.01$
\end{tabular}

$p$-value $>0.05$ : Non significant.

$p$-value $<0.05$ : Significant.

$p$-value $<0.01$ : Highly significant.

Table (5): Diagnostic performance of A-FABP, TG and their combined use for discriminating between SubGroup Ib and combined SubGroup Ia with Group II.

\begin{tabular}{lllllll}
\hline Parameter Cutoff & $\begin{array}{c}\text { \% Speci- } \\
\text { ficity }\end{array}$ & $\begin{array}{c}\text { \% Sensi- } \\
\text { tivity }\end{array}$ & $\begin{array}{c}\% \\
\text { NPV PPV }\end{array}$ & $\begin{array}{c}\% \\
\text { Effi- } \\
\text { ciency }\end{array}$ \\
\hline TG. & $144 \mathrm{mg} / \mathrm{dL}$ & 86.7 & 53.3 & 78.8 & 66.7 & 75.6 \\
A-FABP & $8 \mathrm{ng} / \mathrm{mL}$ & 96.7 & 76.7 & 89.2 & 92 & 90 \\
$\begin{array}{l}\text { Combined } \\
\text { TG and }\end{array}$ & $88 \mathrm{mg} / \mathrm{dL}$ & 98.3 & 100 & 100 & 96.8 & 98.9 \\
A-FABP & $8 \mathrm{ng} / \mathrm{mL}$ & & & & & \\
\hline
\end{tabular}

\section{Discussion}

Patients with MetS have two- to three-fold increased risk for the development of cardiovascular morbidity and mortality [9]. In nearly $20-25 \%$ of apparently healthy individuals and in $45 \%$ of patients with clinical manifestations of atherosclerosis and MetS is present [10]

Adipose tissue plays a key role in the development of insulin resistance and its pathological squealed, such as type 2 diabetes, MetS and nonalcoholic fatty liver disease. Dysfunction in the adipose tissue response to storing excess fatty acids as TG can lead to adipose tissue inflammation and spillover of fatty acids from this tissue and accumulation of fatty acids as lipid droplets in ectopic sites, such as liver and muscle [11]

The adipokine A- FABP, also known as FABP4 or aP2, is not abundantly expressed in adipocytes, but also produced in macrophages, endothelial cells and glial cells. A-FABP functions as a lipid chaperone that regulates trafficking, fluxes and signaling of FFAs, and has an important role in linking lipid metabolism with inflammation [12].

In humans, a promoter polymorphism, T-87C, of the A-FABP gene that resulted in reduced adipose tissue A-FAPB mRNA expression was found to be associated with reduced risk for type $2 \mathrm{DM}$ and cardiovascular diseases [13]. Based on these findings, the present study hypothesized that serum AFA BP level may be a useful marker for identifying DM patients susceptible to developing MetS as well as its evaluation as a predictor marker for MetS.

The results of the present study showed a highly significant increase in serum A-FABP levels in diabetic patients with MetS when compared to the diabetic subjects without MetS. Furthermore, elevated serum A-FABP levels were positively correlated with markers of MetS namely weight and $\mathrm{BMI}$ in sub-group Ib. These findings are in accordance with those of $\mathrm{Xu}$ et al. [14], Yeung et al. [15] and Mauvais [16]. These results are explained by the fact that adipose tissue is probably a significant contributor of A-FABP into the circulatory system through Extracellular vesicles. Therefore; A-FABP might clinically serve as a marker for adiposity which in turn is an important component of MetS $[14,16]$

Subcutaneous adipose tissue functions as a storage depot for excess fatty acids, visceral adipose tissue is more closely linked to the adverse metabolic and inflammatory profile observed in indi- 
viduals with obesity and insulin resistance [17] When individuals become obese, their excess caloric intake is stored in the form of triglycerides within the adipocytes of white adipose tissue. Excess fatty acids are stored in existing mature adipocytes leading to an increase in their size (hypertrophic expansion) [18]. Larger adipocytes tend to be more dysfunctional, and they become insulin resistant resulting in increased lipolysis due to resistance to the anti-lipolytic effects of insulin [19]. Failure of angiogenesis and provision of an adequate blood supply to hypertrophic adipocytes leads to necrosis, macrophage infiltration into adipose tissue and inflammation and adipokine release specially A-FABP. "Spillover" of fatty acids unable to be retained in subcutaneous adipocytes leads to an increase in the visceral fat compartment and eventually flux of fatty acids into ectopic sites, stored as intracellular lipid droplets in tissues, such as liver and the pancreas. The formation of ectopic fat is closely linked to the development of IR and Type $2 \mathrm{DM}$ and metabolic disease [20].

In the present study, notably, the stepwise linear regression analysis adds power to our findings that the best increase in the sensitivity for A-FABP to detect MetS patients was achieved by adding TG. Therefore, A-FABP and TG levels were being the least most sensitive predictor for development of MetS with type $2 \mathrm{DM}$ in studied population. These findings are in accordance with the previous findings of Terra et al. [21] and $\mathrm{Li}$ et al. [22] who found through a logistic regression analysis that A-FABP concentration is the only cytokine significantly increases in patients with MetS than patients without. The relationship between A-FABP and lipid metabolism was partly explained by several studies Oram and Lawn, [23] ; Makowski et al. [24] and Park et al. [25] who reported that A-FABP altered the cholesterol efflux pathway in macrophages. AFABP is a critical regulator of the peroxisome proliferator-activated receptors-liver $\mathrm{X}$ receptor a-adenosine triphosphate (ATP)-binding cassette A1 (ABCA1) pathway and contributes to the control of cholesterol trafficking in macrophages. (ABCA1) regulates the rate-limiting step in HDL biogenesis via the efflux of intracellular cholesterol, which might stimulate transfer of triglycerides to HDL and triglycerides catabolism. However, the pathologic effect of A- FABP at a cellular level requires clarification with further researches [25]

In an attempt to find a laboratory tool that can discriminate diabetic patients with metabolic syndrome from diabetic patients without MetS combined with control group, ROC analysis was constructed for A-FABP and the best chosen cut-off in discriminating between groups was $8 \mathrm{ng} / \mathrm{mL}$ showing $76.7 \%$ diagnostic sensitivity, $96.7 \%$ diagnostic specificity, $92 \%$ positive predictive value, $89.2 \%$ negative predictive value $90 \%$ diagnostic efficacy and area under the curve (AUC) of 0.904. These remarkable findings were improved in combined use of A-FABP and TG reaching excellent diagnostic performance in discriminating diabetic patients with MetS versus those without, where the AUC approached 1.0 (0.987). The best diagnostic cut-off levels of the A-FABP and TG were $8 \mathrm{ng} / \mathrm{mL}$ and $88 \mathrm{mg} / \mathrm{dL}$, respectively, achieving diagnostic sensitivity, diagnostic specificity, positive predictive value, negative predictive value and diagnostic efficacy of $100 \%, 98.3 \%, 96.8 \%$, $100 \%$ and $98.9 \%$, respectively. To our knowledge no other studies had discussed the association between A-FABP and TG as diagnostic tool for MetS.

In accordance with our findings, a previous study by Stejskal and Karpisek [26] conducted on 67 healthy subjects and 71 subjects with metabolic syndrome in a Caucasian population showed that A-FABP at a cut-off level of $16.4 \mathrm{ng} / \mathrm{mL}$ revealed sensitivity of (40\%), specificity of (99\%) and AUC was 0.77 .

hsCRP as a marker of inflammation and a part of the cardiac risk assessment was analyzed to explore its pathologic effect in MetS and its correlation with A-FABP in such patients. In our study, hsCRP levels didn't significantly differentiate between patients with MetS from those without, as well as it was not correlated with A-FABP levels, these in agreement with Grundy [27] and Makowski et al. [24] studies. On the other hand, other studies hypothesized that A-FABP could be a marker for inflammation and MetS through a positive relationship between A-FABP and systemic inflammation reflected by C-reactive protein [28] .

Although, several studies showed that A-FABP has a causal role in systemic inflammation, leading to the development of MetS, it appears that the relationship between A-FABP and MetS was independent of the presence of inflammatory markers. The mechanism remains unclear and excessive productions of A-FABP by obese adipose tissue do not fully overlap those of the inflammatory pathways [25].

A cornerstone in our study was the assessment of the correlation between A-FABP, F.insulin and HOMA-IR. A remarkable finding was that the non significant correlation between A-FABP, F.Insulin and HOMA-IR in diabetic patients with MetS. 
These results are in agreement with those of Eckel et al. [29]; Xu et al. [30]; Tso et al. [31] and Park et al. [25] who explained that plasma A-FABP level was found to be a strong predictor of metabolic syndrome in type $2 \mathrm{DM}$ patients independently of the traditional risk factors including insulin resistance and glycemic indexes. In addition study of Karpisek et al. [32] suggests that an elevated baseline A-FABP level may enhance the MetS phenotype via mechanisms other than insulin resistance.

On the other hand, Tso et al. [31] and Li et al. [22] reported that elevated baseline serum A-FABP levels predict the development of type $2 \mathrm{DM}$ and development of insulin resistance as A-FABP positively correlated with insulin levels. Although the precise mechanisms explaining the role of A-FABP in glucose metabolism are not yet fully understood, the link between A-FABP and adipose tissue may affect glucose metabolism [33]

Selective deletion of A-FABP in adipocytes resulted in reduced expression of inflammatory cytokines in macrophages, whereas the same deletion in macrophages leads to enhanced insulin signaling and glucose uptake in adipocytes [34] Therefore, there is a possibility that A-FABP might affect interactions between adipocytes and macrophages, leading to altered insulin sensitivity and glucose metabolism.

The results of the present study showed a highly significant increase in serum A-FABP levels in diabetic subjects with MetS, when compared to diabetic patients without MetS and healthy control group. Furthermore, elevated serum A-FABP levels were positively correlated with markers of MetS weight and BMI. Further studies are required to elucidate the relationship between A-FABP and development of DM and medication used.

\section{Conflict of interest:}

All authors declare that they have no financial or institutional interests related to this manuscript.

\section{References}

1- HASLAM D.W. and JAMES W.P.: Obesity. Lancet, 366 (9492): 1197-209, 2005.

2- GUSTAFSON B.: Adipose tissue, inflammation and atherosclerosis. J. Atheroscler Thromb., 30; 17 (4): 33241, 2010.

3- WANG S., YANG W., LUO T. and JING Y.: Serum endocan-1 levels are correlated with the presence and severity of coronary artery disease in patients with hypertension. Genet Test. Mol. Biomarkers, 19: 124-127, 2015.

4- DORCELY B., KATZ K., JAGANNATHAN R., CHIANG S.S., OLUWADARE B., GOLDBERG I.J. and BERG-
MAN M.: Novel biomarkers for prediabetes, diabetes, and associated complications. Diabetes, Metabolic Syndrome and Obesity: Targets and Therapy, 10: 345, 2017.

5- American Diabetes Association: Classification and diagnosis of diabetes. Sec. 2. In Standards of Medical Care in Diabetes. Diabetes Care, 39 (1): S13-S22, 2016.

6- LIN C.C., LIU C.S., LI C.I., LIN W.Y., LAI M.M., LIN T., CHANG P.C., LEE Y.D., CHEN C.C., LIN C.H. and YANG C.W.: The relation of metabolic syndrome according to five definitions to cardiovascular risk factors-a population- based study. BMC Public Health, 9 (1): 484, 2009.

7- SHIRAI K.: Obesity as the core of the metabolic syndrome and the management of coronary heart disease. Curr. Med. Res. Opin., 20 (3): 295-304, 2004.

8- LEDUE T.B. and RIFAI N.: Preanalytic and Analytic Sources of Variations in C-Reactive Protein Measurement In Cardiac Markers. Humana Press, Totowa, NJ, 305-3 17, 2003.

9- GRUNDY S.M.: Metabolic syndrome update. Trends in Cardiovascular Medicine, 26 (4): 364-373, 2015.

10- SINGH A.K. and KARI J.A.: The metabolic syndrome and chronic kidney disease. Curr. Opin. Nephrol. Hypertens, 22: 198-203, 2013.

11- GAO X., SALOMON C. and FREEMAN D.J.: Extracellular vesicles from adipose tissue a potential role in obesity and type 2 diabetes?. Frontiers in Endocrinology, 8: 202, 2017.

12- TERRA X., QUINTERO Y., AUGUET T., PORRAS J.A., HERNÁNDEZ M., SABENCH F., AGUILAR C., LUNA A.M., DEL CASTILLO D. and RICHART C.: FABP 4 is associated with inflammatory markers and metabolic syndrome in morbidly obese women. European Journal of Endocrinology, 164 (4): 539-47, 2011.

13- TUNCMAN G., ERBAY E., HOM X., De VIVO I., CAMPOS H., RIMM E.B. and HOTAMISLIGIL G.S.: A genetic variant at the fatty acid-binding protein aP2 locus reduces the risk for hypertriglyceridemia, type 2 diabetes, and cardiovascular disease. Proc. Natl. Acad. Sci. USA, 103: 6970-6975, 2006.

14- XU A., WANG Y., XU J.Y., STEJSKAL D., TAM S. and ZHANG J.: Adipocyte fatty acid-binding protein is a plasma biomarker closely associated with obesity and metabolic syndrome. Clin. Chem., 52: 405e13, 2006.

15- YEUNG D.C.Y., XU A., CHEUNG C.W.S., WAT N.M.S., YAU M.H., FONG C.H.Y., CHAU M.T. and LAM K.S.L.: Serum adipocyte fatty acid-binding protein levels were independently associated with carotid atherosclerosis in Chinese women. Arterioscler Thromb Vasc Biol., 27: 1796-1802, 2007.

16- MAUVAIS-JARVIS F.: Sex differences in metabolic homeostasis, diabetes, and obesity. Biology of Sex Differences, 6: 14, 2015.

17- MATHIEU P., BOULANGER M.C. and DESPRES J.P.: Ectopic visceral fat: A clinical and molecular perspective on the cardiometabolic risk. Rev. Endocr. Metab. Disord, 15: 289-98, 2014.

18- CUTHBERTSON D.J., STEELE T., WILDING J.P., HALFORD J.C., HARROLD J.A. and HAMER M.: What have human experimental overfeeding studies taught us about 
adipose tissue expansion and susceptibility to obesity and metabolic complications? Int. J. Obes. (Lond), 41 (6): 853-65,2017.

19- IBRAHIM M.M.: Subcutaneous and visceral adipose tissue: Structural and functional differences. Obes. Rev., 11: 11-8, 2010.

20-SATTAR N. and GILL J.M.: Type 2 diabetes in migrant south Asians: Mechanisms, mitigation, and management. Lancet Diabetes Endocrinol., 3: 1004-16, 2015.

21-TERRA X., QUINTERO Y., AUGUST T., PORRAS J.A., HERNANDEZ M., SABENCH F., AGUILAR C., LUNA A.M., DEL CASTILLO D. and RICHART C.: FABP 4 is associated with inflammatory markers and metabolic syndrome in morbidly obese women. European Journal of Endocrinology, 164 (4): 539-47, 2011.

22-LI J.C., WU D.A., HOU J.S., SUBEQ Y.M., CHEN H.D. and HSU B.G.: High Serum Adipocyte Fatty Acid Binding Protein Is Associated with Metabolic Syndrome in Patients with Type 2 Diabetes. J. Diabetes Res., 8380279, 2016.

23- ORAM J.F. and LAWN R.M.: ABCA1. The gatekeeper for eliminating excess tissue cholesterol. J. Lipid Res., 42: 1173-9, 2001.

24- MAKOWSKI L., BRITTINGHAM K.C., REYNOLDS J.M., SUTTLES J. and HOTAMISLIGIL G.S.: The fatty acid-binding protein, aP2, coordinates macrophage cholesterol trafficking and inflammatory activity. Macrophage expression of aP2 impacts peroxisome proliferatoractivated receptor gamma and IkappaB kinase activities. J. Biol. Chem., 280: 12888-95, 2005.

25-PARK S.E., RHEE E.J., LEE W.Y., KIM W.J., YOO S.H., BAE J.C., CHOI E.S., PARK C.Y., OH K.W., PARK S.W. and KIM S.W.: The role of serum adipocyte fatty acidbinding protein on the development of metabolic syndrome is independent of pro-inflammatory cytokines. Nutrition, Metabolism and Cardiovascular Diseases, 22 (6): 52532, 2012.

26-STEJSKAL D. and KARPISEK M.: Adipocyte fatty acid binding protein in a Caucasian population• A new marker of metabolic syndrome?. European Journal of Clinical Investigation, 36 (9): 621-5, 2006.

27- GRUNDY S.M.: Inflammation, hypertension, and the metabolic syndrome. JAMA, 290: 3000-2, 2003.

28-KOH J.H., SHIN Y.G., NAM S.M., LEE MY., CHUNG C.H. and SHIN J.Y.: Serum adipocyte fatty acid-binding protein levels are associated with nonalcoholic fatty liver disease in type 2 diabetic patients. Diabetes Care, 32: 147-52,2009.

29- ECKEL R.H., GRUNDY S.M. and ZIMMET P.Z.: The metabolic syndrome. The Lancet, 365 (9468): 1415-28, 2005.

30- XU A., TSO A.W., CHEUNG B.M., WANG Y., WAT N.M., FONG C.H., YEUNG D.C., JANUS E.D., SHAM P.C. and LAM K.S.: Circulating adipocyte-fatty acid binding protein levels predict the development of the metabolic syndrome. Circulation, 115 (12): 1537-43, 2007.

31-TSO A.W., XU A., SHAM P.C., WAT N.M., WANG Y., FONG C.H., CHEUNG B.M., JANUS E.D. and LAM K.S.: Serum Adipocyte Fatty Acid-Binding Protein as a New Biomarker Predicting the Development of Type 2 Diabetes: A 10-year prospective study in a Chinese cohort. Diabetes Care, 30 (10): 2667-72, 2007.

32-KARPISEK M., STE3sKAL D., HLOZANKOVA M. and RUZICKA V.: Adipocyte fatty acid-binding protein: A predictive marker of metabolic syndrome. Atherosclerosis, 263: 202, 2017.

33-MAEDA K., CAO H., KONO K., GORGUN C.Z., FURUHASHI M. and UYSAL K.T.: Adipocyte/macrophage fatty acid binding proteins control integrated metabolic responses in obesity and diabetes. Cell Metab, 1: 107-19, 2005.

34-FURUHASHI M., TUNCMAN G., GORGUN C.Z., MAKOWSKI L., ATSUMI G. and VAILLANCOURT E.: Treatment of diabetes and atherosclerosis by inhibiting fatty-acid-binding protein aP2. Nature, 447: 959-65,2007. 


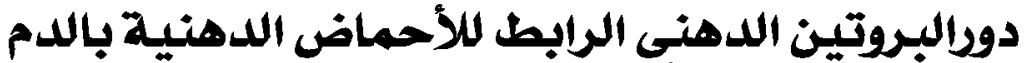

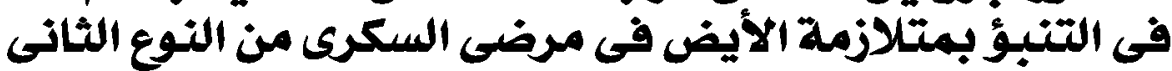

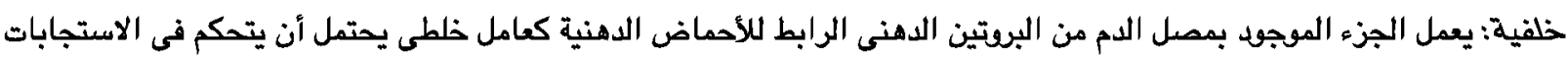

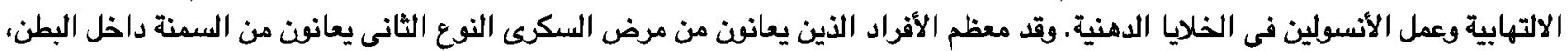
ومقاومة الأنسولين وحدوث متلازمة الأيض.

الهدف: تهدف هذه الدراسة إلى تقييم البرتين الدهنى الرابط للأحماض الدهنية كعلامة لدوث متلازمة الأيض فى مرضى السكرى من النوع الثانى.

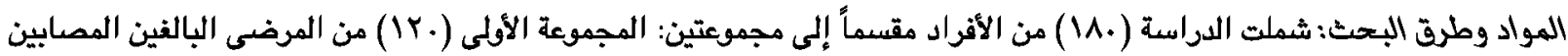

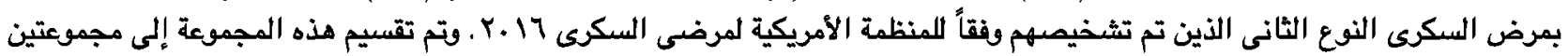

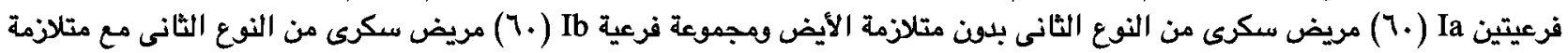

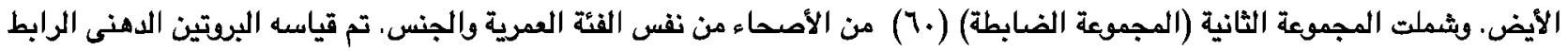

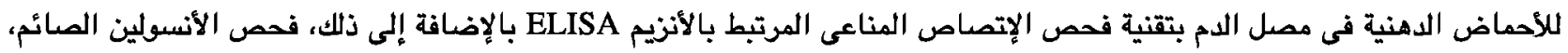

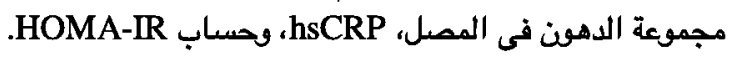

النتائج: لوحظ زيادة كبيرة في مستويات البروتين الدهنى الرابط للأحماض الدهنية، الأنسولين الصائم،

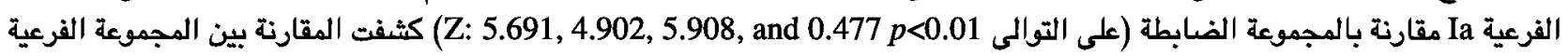
مقابل المجموعة الفرعية Ib

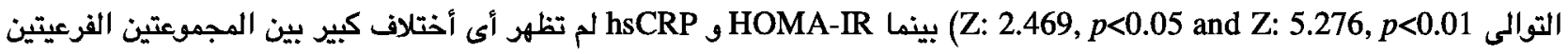

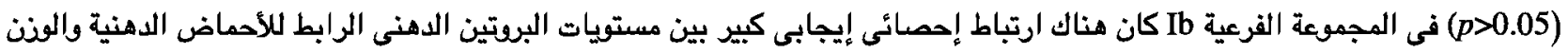

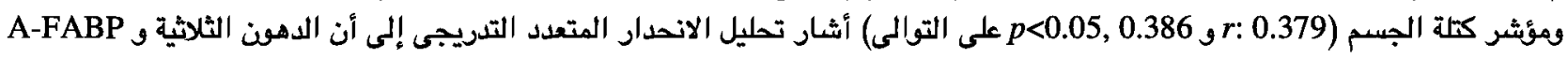

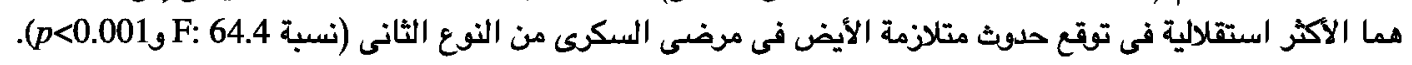

الخذلاصة: يرتبط مستوى المصل المرتفع للبروتين الدهنى الرابط للأحماض الدهنية بشدة مع حدوث متلازمة الأيض فى مرضىى السكرى

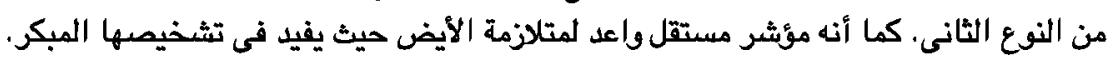

